\title{
Effect Of Water Quality On Phytoplankton Abundance In Hampalam River And Fish Pond Of Batanjung Village
}

\author{
Evi Veronica ${ }^{1}$, Amin Setyo Leksono ${ }^{2 *}$, Soemarno $^{3}$, Diana Arfiati $^{4}$ \\ ${ }^{I}$ Doctoral Program of Agriculture Science. Faculty Of Agriculture, University Of Brawijaya, Indonesia \\ ${ }^{2 *}$ Department of Biology, Faculty of Mathematic and Natural Sc., University Of Brawijaya, Indonesia \\ ${ }^{3}$ Department of Soil Science, Faculty of Agriculture, University Of Brawijaya, Indonesia \\ ${ }^{4}$ Faculty of Fisheries and Marine Science, University Of Brawijaya, Indonesia
}

\begin{abstract}
Phytoplankton is microorganism which possesses important roles in the waters, not only as primary producer in food chain but also one of the parameters for fertility level of the waters. This study was aimed at knowing the phytoplankton dynamics and the water quality of Hampalam River and fish pond in Batanjung Village, Kapuas Regency. The study was carried out from May 2011 to May 2012, and sampling was done 13 sucessive times at 6 station points. Phytoplankton sampling was done using filtering method and physical and chemical parameter measurements were done in situ and laboratory. Results showed that 60 genera of 7 phytoplankton phylla were found in the river and pond, with the highest abundance of Pleurosigma belonging to Chrysophyta in the river and Euglena sp.belonging to Euglenophyta in the pond, respectively. Based upon the phytoplankton structure and aquatic physical and chemical parameters, Hampalam river and public pond were in moderate fertility level or stable ecosystem. DHL, Salinity, total $\mathrm{P}, \mathrm{NO}_{3}, \mathrm{NH}_{3}$, and pH directly affect the phytoplankton.
\end{abstract}

Keywords: effect, phytoplankton, water quality, river, Hampalam, pond.

\section{Iintroduction}

Phytoplankton is natural food for various fishes and shrimps inhabiting first producer level in energy flows. It, as primary producer in the water, is also one of the life sources for all animals. Phytoplankton is dissolved oxygen producer in the water as well. In food chain, phytoplankton is eaten by herbivores (such as zooplankton) which will also be eaten by larger carnivores (fish and others) and etc.

The existence of phytoplankton in the waters can be seen on the basis of their abundance influenced by several environmental parameters and their physiological characteristics. It will change at various levels as a response to the changes in physical, chemical and biological environmental conditions. Factors supporting the phytoplankton growth are very complex and interacting between physical and chemical factors, such as dissolved oxygen, temperature, visibility and the availability of nutrients, nitrogen and phosphorous (Goldman and Horne, 1983).

In river ecosystem occurs water mass mixture and no vertical stratification of the water column is formed. Currents, erosion and sedimentation are common phenomenon in the river affecting the life of aquatic biota. Hampalam river, one of the affluents of Kapuas river, Kapuas Regency with $\pm 7.5 \mathrm{~km}$ long and $\pm 15-17 \mathrm{~m}$ wide, is an aquatic area highly potential for fisheries particularly as fishing ground for shrimp, crab, gobiid, snakehead and others. Along the left and the right of Hampalam river there are public fish ponds which get physical changes after the agricultural and fisheries irrigations were built, changes in land function from forest to plantation and agriculture areas, and increasing human activities along the river. This change causes alterations of aquatic environmental conditions and fish ponds along the river otomatically affect the water quality and the life of aquatic biota especially phytoplankton as primary producer in the water. Therefore, it is necessary to know how the water quality affects the phytoplankton abundance.

This study was aimed to pursue the effect of water quality on the phytoplankton abundance and the phytoplankton structure in Hampalam river and public fish ponds in Batanjung village. The study is expected to be able to give additional field evidence concerning the effect of physical and chemical water quality on the phytoplankton abundance and the phytoplankton structure in Hampalam river and local public fish ponds, so that it could help speeding up the concept or technological development effort in managing the water quality and the phytoplankton abundance development in the most favorable condition and as an effort of sustainable aquatic resources management.

\section{Research Methods}

This study was carried out in May 2011 to May 2012 in Hampalam river and public fish pond in Batanjung, Kapuas Regency. The observations were done in time series at monthly basis and at six stations as follows: 
a. Station I (headwaters), $03^{\circ} 21^{\prime} 51.5^{\prime \prime} \mathrm{S}$ and $114^{\circ} 12^{\prime} 40.8^{\prime \prime} \mathrm{E}$,

b. Station II (Mid Headwaters), 03'21'58.7'S and114'14'17.1'"E,

c. Station III (Mid Downstrean), 03'21'45.3'S and 114'13'23.6”'E,

d. Station IV (Hampalam rivermouth), $03^{\circ} 21^{\prime} 21.5^{\prime \prime} \mathrm{S}$ and $114^{\circ} 14^{\prime} 49.2^{\prime \prime} \mathrm{E}$,

e. Station V (Headwaters pond/Public property1), $03^{\circ} 21^{\prime} 51.5^{\prime \prime} \mathrm{LS}$ and $114^{\circ} 12^{\prime} 40.8^{\prime \prime} \mathrm{E}$,

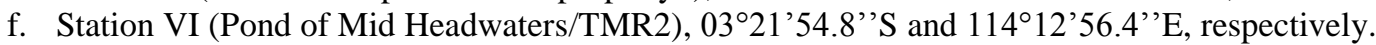

Samples were collected by filtering 30 liters of water using a $20 \mu \mathrm{m}$ plankton net. Samples were put into $20 \mathrm{ml}$ botol containing lugol $1 \%$ solution. Phytoplankton species and abundance were observed using an Olympus, ZX typed-microscope and identified following Newell and Newell, 1963, Yamaji, 1982, and Bold and Wynne, 1985. Water quality was measured in situ covering $\mathrm{pH}$, temperature, DO, and salinity using HORIBA Water Quality Checker u10, visibility with Secchi disc, depth with depth sounder, and $\mathrm{NO}_{3}$ and $\mathrm{PO}_{4}$ with spectrophotometer in the laboratory.

Phytoplankton abundance was estimated using APHA (1985), while diversity index and dominance index with Shanon-Wiener (Shannon index) method. Eveness index was measured with Simpson index and BrayCurtis equation. Statistical analysis was applied to know the effect of water quality on the phytoplankton abundance using Multivariate Statistics and version 20-SPSS.

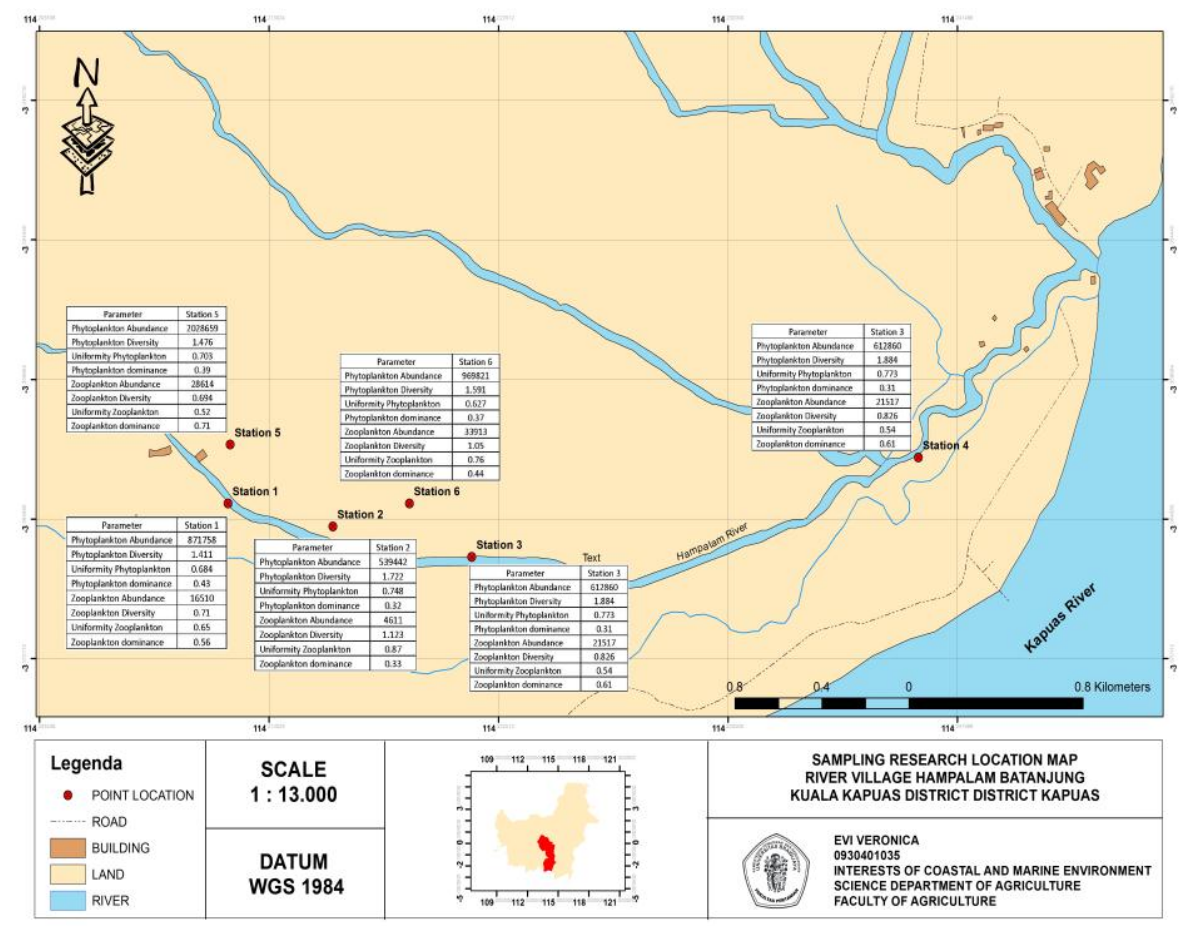

Figure 1 : Research Location Map

Water Quality

III. Empirical Result

Measurement data of water quality (physical and chemical parameters) are completely given in Table 1.

Table 1. Mean value of aquatic physical-chemical parameters in each station of Hampalam River and fish pond (TMR) of Batanjung village, Kapuas Regency.

\begin{tabular}{|l|c|c|c|c|c|c|}
\hline Parameters & Sta. I & Sta.II & Sta. III & Sta. IV & Sta. V & Sta. VI \\
\hline Visibility $(\mathrm{cm})$ & 27.65 & 21.00 & 18.23 & 18.92 & 21.15 & 22.45 \\
\hline Temperature $\left({ }^{\circ} \mathrm{C}\right)$ & 30.22 & 29.91 & 29.66 & 29.55 & 30.65 & 30.18 \\
\hline DHL $(\mu \mathrm{mhos} / \mathrm{cm})$ & 7.75 & 7.54 & 6.90 & 8.01 & 7.78 & 7.92 \\
\hline $\mathrm{DO}(\mathrm{mg} / \mathrm{L})$ & 3.30 & 3.29 & 3.05 & 3.47 & 3.12 & 3.15 \\
\hline $\mathrm{pH}$ & 6.11 & 6.12 & 6.08 & 5.72 & 6.05 & 6.13 \\
\hline $\mathrm{NO}_{3}(\mathrm{mg} / \mathrm{L})$ & 0.06 & 0.06 & 0.06 & 0.05 & 0.10 & 0.05 \\
\hline Salinity $(\mathrm{ppt})$ & 0.44 & 0.42 & 0.48 & 0.54 & 0.44 & 0.43 \\
\hline Total P $(\mathrm{mg} / \mathrm{L})$ & 0.04 & 0.03 & 0.07 & 0.11 & 0.18 & 0.32 \\
\hline NH $(\mathrm{mg} / \mathrm{L})$ & 0.01 & 0.02 & 0.01 & 0.03 & 0.02 & 0.02 \\
\hline Current speed $(\mathrm{cm} / \mathrm{s})$ & 21.80 & 14.42 & 15.06 & 18.15 & - & - \\
\hline Depth $(\mathrm{cm})$ & 114 & 114 & 285 & 179 & 87 & 84 \\
\hline
\end{tabular}


In general, visibility is increasingly lower toward the river mouth. According to Siahaan et al. (2011), water visibility was getting lower toward the downstream. As a consequence, light penetration into the water reduces and then will also reduce the photosynthetic rate and the primary productivity of the phytoplankton (Nybakken, 1992). Moreover, the temperature range of $29.8-30.4{ }^{\circ} \mathrm{C}$ is good for the phytoplankton. It is in agrreement with Effendi (2003) that the optimum temperature for phytoplankton growth ranged from $20-30^{\circ} \mathrm{C}$.

Dissolved oxygen recorded in this study, 3.05-3.47 mg/L, was low. According to Bolorunduro and Abba (1996), fish will reduce their feeding in low dissolved oxygen condition, about $3 \mathrm{mg} / \mathrm{L}$. Low DO indicates that the photosynthetic process is not good due to low water visibility making the light penetration cannot reach the deep waters. Based on Government Regulation Numnered 82, 2001, oxygen concentration for fisheries must be $>3 \mathrm{mg} / \mathrm{L}$, so that Hampalam river could be suitable for aquatic organisms.

According to Effendi (2003), nitrate concentration in Hampalam river and fish pond is categorized as low fertility level (oligotrophic), while according to Wetzel (2001), total phosphate concentration in Hampalam river indicates high fertility (eutrophic). High phosphate concentration could result from several factors, one of which is much sediment in the waters. According to Karels and Serge (2010), high phosphate in natural waters could also result from sediment composition in the waters.

\section{Phytoplankton Structure}

This study found 60 species of phytoplankton consisting of Chrysophyta (46\%), Chlorophyta (35\%), Euglenophyta (11\%), Cyanophyta (3\%) and Mastigopora, Chloromonadopora, and Pyrrophyta (1\% each). High Chrysophyta in the river and ponds could result from that it is freshwater phyllum, while in seawater the phytoplankton possessing important role for fisheries is diatom. As primary producer, diatom is eaten by zooplankton, fish larvae and small fishes. The phytoplankton composition and abundance are highly affected by environmental conditions that could support their life and grazing by zooplankton and other planktivores.

The occurrence of phytoplankton at one point of the river could only describe an instantineous environmental condition of the water due to depending upon the current velocity of the river, physical changes after building the irrigation for agriculture and fisheries, change in land use from forest to plantation and agricultural areas, and higher human activities along the watershed affecting the phytoplankton occurrence. Rodrigues, LC. et al. (2009) studying the species richness and the density of phytoplankton in Parana river before reservoir development (1993-1994) and 8 years after reservoir development (2000-2007) in the headwaters found that there was significant difference between the two periods in which decline in phytoplankton species richness occurred after the reservoir development. As a whole, algal density decreased in $2005-2007$.

The present study found that mean range of the phytoplankton diversity index $\left(\mathrm{H}^{\prime}\right)$ in the river and pond was low $(<2.306)$. The lower the $\mathrm{H}^{\prime}$ value the lower the phytoplankton diversity, and this condition highly influences the water stability and living environment, but it will easily change with relatively small environmental influence. Eveness index (E) was high in the river and pond (Odum, 1993). This is reciprocal to dominance index (D) with a range of 0-1, in which if the eveness index is high (approach to 1), there is no species dominance and vice versa. It is suppored by Pirzan et all (2005) that if eveness index approaches to zero, the species eveness in the commuunity is low and inversely if the eveness index approaches to 1 the spesies in the community is the same. The present study finding the eveness index approaching to 1 and 0 could understood that there is no species dominating the Hampalam river and the public ponds meaning that the aquatic ecosystem is still stable. Mean biotic index of the phytoplankton during the study is given in Fig. 2.

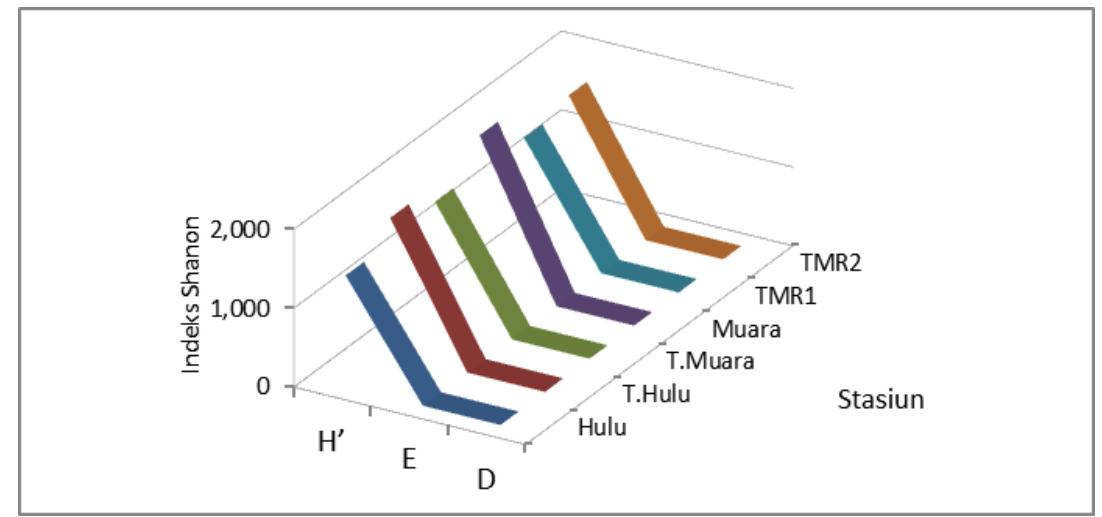

Figure 2. Diversity (H'), eveness (E) and dominance (D) indices of phytoplankton

Phytplankton abundance per station ranged from 539,442 to 871,758 ind/L in the river and from $1,025,706$ to $2,028,659 \mathrm{ind} / \mathrm{L}$ in the pond. High phytoplankton abundance in the pond could result from good 
range of total phosphate concentration in the pond promoting the phytoplankton growth, while limited phytoplankton abundance in the pond is due to river current and current velocity dependence.

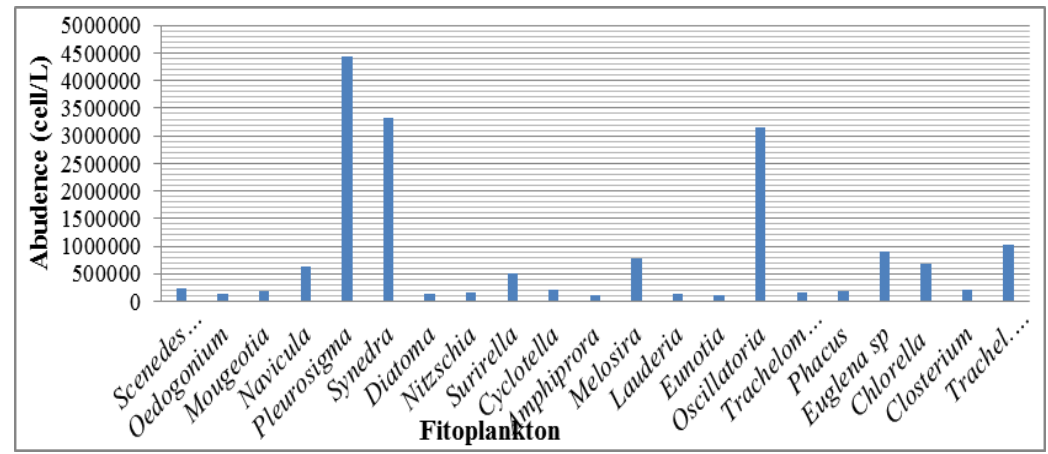

Figure 3. Phytoplankton abundance (cells/L) in Hampalam river

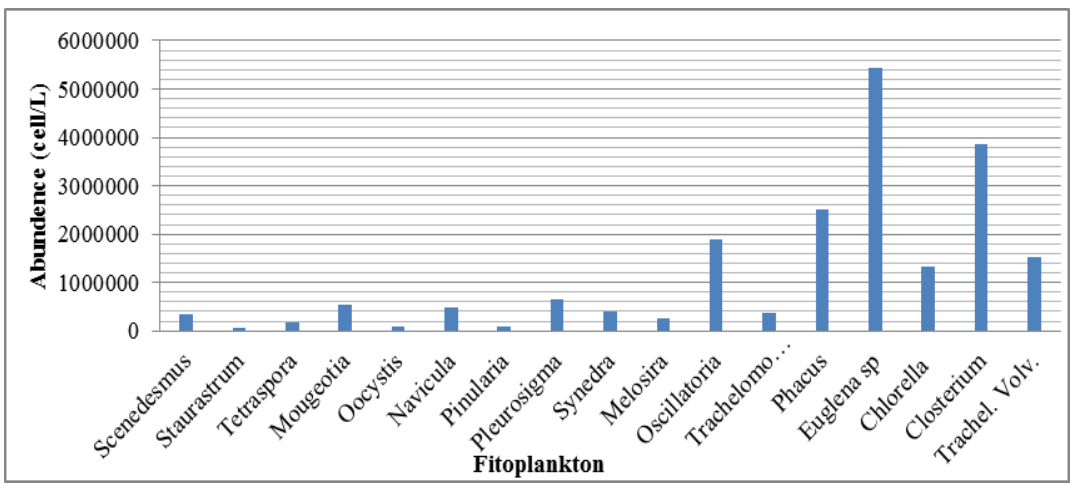

Figure 4. Phytoplankton abundance (cell/L) in public ponds (TMR)

Species with the highest abundance in the river was Pleurosigma (14\%) of Chrysophyta and in the pond was Euglena sp.(32\%) of Euglenaphyta. Genus Pleurosigma is freshwater diatom which is cosmopolite and multiplies by cell division. Its cell division rate is higly dependent upon the environmental condition and the species. Scientists agree that in tropical waters, the cell diatom division could be faster. It is in line with Chua (1970) that cell division in tropical waters will be faster. High abundance of Euglena sp. In the public pond colud result from that it belongs to mobile organisms that could freely move with flagella, live in freshwater and could live in the soil at aquatic plant roots. High or low abundance of the phytoplankton is also dependent upon the aquatic environmental condition partocularly the availablity of nutrients $\mathrm{N}$ and $\mathrm{P}$, and each spesies or group of phytoplankton has different reaction to nutrients causing their abundance could be different in different body of waters.

Low fertile waters has plankton abundance less than $10^{4} \mathrm{ind} / \mathrm{L}$, moderate fertile does higher than $10^{4}$ ind/L, and very high fertile does $10^{7} \mathrm{ind} / \mathrm{L}$, while plankton abundance higher than $10^{7} \mathrm{ind} / \mathrm{L}$ is called blooming (Goldman and Horne,1983). Thus, Hampalam river and public ponds in Batanjung village for 13 periods of observations possessing mean range of phytoplankton abundance per station as many as 539,442 - 2,028,659 ind/L belong to moderate fertility level category.

For phytoplankton normality and abundance test by comparing the phytoplankton abundance data in river and pond, the present study found the the F value of 0.372 with $\mathrm{P}>0.05$ meaning that both populations were identical or possessing homgeneous variance. Beside that, the significance value of $t$ was obtained 0.244 . Since the significance value of $t$ is bigger than 0.05 there is no difference between the phytoplankton abundance in the river and pond. In this study 60 species in the river and 54 species in the pond were recorded with mean abundance of 1,114,624 ind/L for pond and $648,350 \mathrm{ind} / \mathrm{L}$ for river.

\section{Effect of Water Quality on Phytoplankton Abundance}

To know direct or indirect effect of physical and chemical parameters on plankton and gobiid juveniles, multivariate statistical method, such as Path analysis and PCA, was used. 
PATH Analysis.

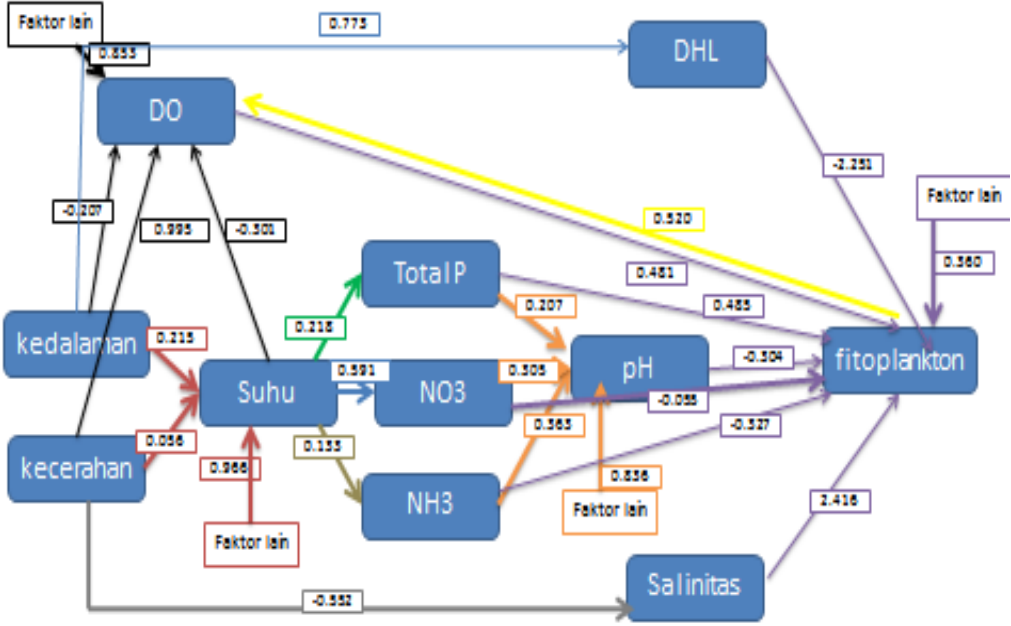

Figure 5. Path Analysis of physical, chemical, phytoplankton parameters.

Path analysis above (Fig. 5) describes the relationship and direct and indirect effects of water quality on the phytoplankton. Different line colors indicates different analyses, in which the same color represents the output of similar analysis. Red color (temperature, visibility and depth) means that water depth and visibility affects water temperature as much as $3.4 \%$, and the rest $96.6 \%$ is influenced by other factors. Black color (temperature, visibility, DO and depth) indicates that DO is affected by water temperature, depth, and visibility as much as $14.7 \%$, and the rest $85.3 \%$ is affected by other factors, while water depth and temperature negatively influence DO or there is a trade-offs, meaning that increased water depth and temperature will cause DO decline and vice versa. In the river, water temperature, depth and visibility directly affect the photosynthetic rate. Increased water temperature results in reduction in dissolved oxygen that eventually affect the the life of aquatic organisms (Moriber, 1974).

Green color (temperature and total $\mathrm{P}$ ) shows that water temperature influences the total $\mathrm{P}$ concentration as much as $4.8 \%$, and the rest $95.2 \%$ of total $\mathrm{P}$ is affected by other factors. Brown color (temperature and $\mathrm{NH} 3$ ) indicates that water temperature influences the $\mathrm{NH} 3$ concentration as much as $1.8 \%$, and the rest $98.2 \%$ is affected by other factors. Orange color (total $\mathrm{P}, \mathrm{NH} 3, \mathrm{NO} 3$ and $\mathrm{pH}$ ) reflects that total $\mathrm{P}, \mathrm{NO} 3$ and NH3 affect the water $\mathrm{pH}$ as much as $7.8 \%$, and the rest $92.2 \%$ is affected by other factors. Grey color (visibility and salinity) shows that water salinity is influenced by visibility as much as $30.5 \%$, and the rest $69.5 \%$ is affected by other factors.

Purple color ( $\mathrm{pH}, \mathrm{DO}$, salinity, DHL, total $\mathrm{P}, \mathrm{NO} 3, \mathrm{NH} 3$ and phytoplankton indicates that phytoplankton occurrence is affected by $\mathrm{pH}, \mathrm{DO}$, salinity, total $\mathrm{P}, \mathrm{NO} 3$, and $\mathrm{NH} 3$ as much as $63.8 \%$, and the rest $36.2 \%$ of the occurrence is affected by other factors. Blue color (depth and DHL) shows that water depth influences DHL as much as $59.8 \%$, and the rest $40.2 \%$ is affected by other factors. Yellow color (phytoplankton and DO) indicates that phytoplankton affects dissolved oxygen (DO) as much as $27.1 \%$, and the rest $72.9 \%$ of DO is inflenced by other factors. There is mutual influence between DO and phytoplankton, in which DO has direct influence on phytoplankton and vice versa, because phtoplankton is aquatic flora conducting photosynthetic process and becoming DO source in the waters. Tinginya faktor lain yang berpengaruh terhadap DO dan fitoplankton disebabkan karena fitoplankton dan DO di perairan sama-sama punya peranan penting bagi organisme di perairan sehingga keberadaannya sangat dipengaruhi beberapa faktor lingkungan fisik perairan.

DHL, $\mathrm{NO}_{3}, \mathrm{NH}_{3}$, and $\mathrm{pH}$ negatively influence the phytoplankton meaning that if DHL, NO3, NH3 and $\mathrm{pH}$ are high, thephytoplankton is low and vice versa. Furthermore, DHL, salinity, total $\mathrm{P}, \mathrm{NO}_{3}, \mathrm{NH}_{3}$, and $\mathrm{pH}$ directly affect the phytoplankton, while water depth, visibility, and temperature do not directly affect the phytoplankton. $\mathrm{NO}_{3}$ and total Phosphate are nutrients for phytoplankton growth, while $\mathrm{NH} 3$ is a reduction output of NO3 and phytoplankton excretion. Webber D.F et all (1995) found that as limiting fator, high productivity in marine ecosystem was affected by nitrogen, but in freshwater ecosystem, it was affected by phosphate concentration. Change in one of the environmental factors will influence the phytoplankton diversity. Saravi H. N. et al (2011) suggested that majority of phytoplankton species possesses large tolerance to different water quality and influence of water quality on the phytoplankton communities varied from year to year. 
PCA Analysis

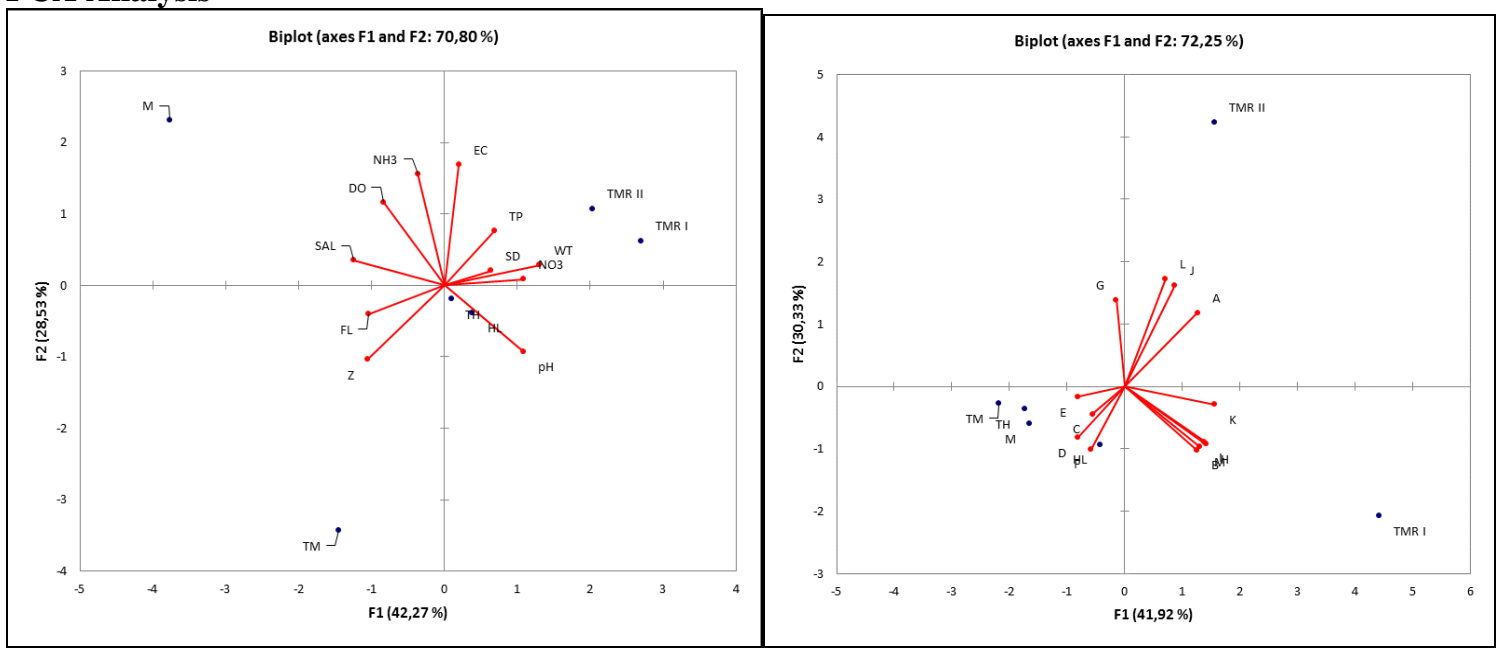

Figure 6. Water quality with station Figure 7. Phytoplankton species abundance with station

Based on PCA (Bi Plot) analysis of water quality parameters in each station (Fig. 6), it could be assumed that station $\mathrm{M}$ (rivermouth) is characterized with high salinity, $\mathrm{DO}$ and $\mathrm{NH}_{3}$. In contrast, other stations possess low salinity, DO and $\mathrm{NH}_{3}$. Station TM (T. rivermouth) is characterized with high current velocity FL) and depth Z. Station TH (T. headwaters) and HL (headwaters) are characterized with high pH dan visibility SD. Station TMR I (public pond I) and TMRII (public pond II) is characterized with high EC (DHL), total P, WT (temperature), $\mathrm{SD}$ (visibility) and $\mathrm{NO}_{3}$, but low other parameters. High salinity, DO and $\mathrm{NH} 3$ in station rivermouth could result from that Hampalam river is an affluent of Kapuas river existing exactly in Kapuas rivermouth so that its salinity is affected by periodic seawater inclusion as in dry season, water input, and high human activities in the rivermouth could also cause high DO and NH3. However, high DHL, total P, temperature, visibility and NO3 in station TMR I and TMR II could result from activities in the pond as culture medium of tilapia (Oreochromis niloticus) and iridescent shark (Pangasius sp.). PCA (Bi Plot) analysis on phytoplankton species in each station (Fig. 6) could be assumed that station TMR II (public pond II) is characterized with high phytoplankton abundance of species L (Closterum), J (Euglena) and A (Scenedesmus). Nevertheless, the abundance of these species is low in other stations. Station TMR I (public pond I) is characterized with high phytoplankton abundance of species K (Chlorella sp.), B ( Navicula sp.), $\mathrm{H}$ (Trachelomonas sp.), M ( Trachelomonas volvoc), N (Melosira) and I (Phacus). While station TM (T. Rivermouth), TH (T. headwaters), M (rivermouth) and HL (headwaters) are characterized with high phytoplankton abundance of species E (Surilla), C (Pleurogsima), D (Synedra) and F (Eunotia), and species G (Oscillatoria) is closer to station HL (headwaters).

Based upon PCA (Bi Plot) analyses on water quality and on species abundance, it is concluded that DHL, temperature, visibility, total phosphate and $\mathrm{NO}_{3}$, affect the phytoplankton abundance of Closterum, Euglena, Scenedesmus, Chlorella, Navicula, Trachelomonas, Trachelomonas volvoc, Melosira and Phacus, while water depth, current velocity, visibility, pH, DO, NH3 and salinity influence the phytoplankton abundance of Surilla, Pleurosigma, Synedra dan Eunotia. Nevetherless, Oscillatoria is affected by water visibility and $\mathrm{pH}$. In public ponds, there was high phytoplankton abundance, particularly Euglena. It could result from environmental factors, especially nitrate, phosphate, and temperature to support their growth. Phytoplankton occurrence is affected by the availability of nutrients, sunlight and temperature (Lismining and Satria (2009). In tropical river, the phytoplankton biomass is affected not only by nutrients but also by rainy and dry seasons, in which in rainy season water agitation occurs causing turbidity and low light intensity (Soares M.C.S et al., 2007). High abundance of Pleurosigma in Hampalam river is supported by environmental factors, particularly water $\mathrm{pH}$, salinity, $\mathrm{DO}$ and $\mathrm{NH}_{3}$.

The study of Piirsoo K., et al 2004 showed that in Estonia river, the phytoplankton composition is heterogenous, their development is highly dependent upon the light condition and vegetations in the river bank. In big and small rivers, phytoplankton is quantitatively an pa potency indicator for river ecological status.

\section{Cconclusion}

The study identified 60 species of phytoplankton from 7 phylla, Chrysophyta, Chlorophyta, Euglenophyta, Cyanophyta, Pyrophyta, Mastigopora and Chloromonadophyta. Genus with the highest abundance in the river was Pleurosigma belonging to Chrysophyta division, and in the pond Euglena sp. from 
Euglenaphyta division. The phytoplankton structure Hampalam river and public pond had low diversity, high eveness and low dominance, while their abundance between the river and the pond was not different. Based upon their abundance, both Hampalam river and pond were categorized possessing moderate fertility level or belonged to stable ecosystem.

Observations Hampalam River water quality and pond belongs to the people of the village Batanjung brightness parameters, $\mathrm{pH}, \mathrm{DO}$ and $\mathrm{NO} 3$ are low or below the standards set for the needs of aquatic organisms whereas both parameters including total phosphate that can be utilized by phytoplankton for growth.

Parameters DHL, salinity, total P, NO3, NH3, and pH directly affect phytoplankton. DHL parameters, temperature, brightness and total Phosphate NO3 Closterum affect the abundance of species, Euglena, Scenedesmus, Chlorella, Navicula, Trachelomonas, Trachelomonas volvoc, Melosira and Phacus. Parameter depth, current speed, brightness, $\mathrm{pH}, \mathrm{DO}, \mathrm{NH} 3$ and salinity affect the abundance of species Surilla, Pleurosigma, Synedra and Eunotia. While Oscillatoria species is affected by brightness and $\mathrm{pH}$ parameters

\section{Rreferences}

[1]. APHA (American Public Health Association). 1985. Standard Methods for the Examination of Water and Wastewater. 16 edn.APHA, AWWA and WPCF.Washington DC.

[2]. Bolorunduro, P.I dan Y.A. Abba. 1996. Water Quality Management in Fish Culture. Extension Bulletin No. 98. Fisheries Series No. 3. National Agricultural Extention and Research Liaison Services Ahmadu Bello University. Zaria. 53 pp.

[3]. Chua, T.E. 1970. A Preliminary Study On The Plankton of The Ponggol Estuary. Hydrobiology 35 (2) : $254-272$.

[4]. Effendi, H. 2003.Telaah Kualitas Air.Bagi Pengelolaan Sumberdaya dan Lingkungan Perairan.Kanasius, Jogyakarta.Indonesia.

[5]. Goldman, C.R. dan Horne, A.J. 1983.Limnology. McGraw-Hill Book Company. New York, USA. 464 p.

[6]. Karels, J. dan S.N. Petnkeu. 2010. Determination of Phosphate, Nitrate, and Sulfate in the Red River by Ion Chromatography. Concordia College Journal of Analytical Chemistry 1 (2010), 24-28.

[7]. Lismining, P.A dan Satria, H. 2009.Kelimpahan dan Komposisi Fitoplankton di Danau Sentani, Papau.Limnotek.Perairan Darat Tropis di Indonesia. Vol. XVI. 88-98.

[8]. Moriber G. 1974. Environmental Science. Boston. Broklyn College, Allyn and Bacon Inc

[9]. Nybakken, J.W. 1992.Biologi Laut.Suatu Pendekatan Ekologis.Terjemahan dari Marine Biologi:An Ecological Approach.Alih Bahasa: M. Eidman, Koesoebiono, D.G. Bengen \& M. Hutomo.Gramedia, Jakarta. 459 p.

[10]. Odum,E.P. 1993.Dasar-Dasar Ekologi (Terjemahan). Edisi Ketiga. Gajah Mada University Press. Yogyakarta.

[11]. Peraturan Pemerintah Nomor 82 Tahun 2001 Tentang Pengelolaan Kualitas Air dan Pengendalian Pencemaran Air. Lampiran Kriteria Baku Mutu Air. Jakarta. 28 hlm.

[12]. Piirsoo K., Pall P., Viik M. 2004. Phytoplankton characteristics for different types of Estonian rivers. Oceanological and Hydrobiological Studies. International Journal of Oceanography and Hydrobiology. Vol XXXIII, No. 1, Institute of Oceanography ISSN 1730-413X, (23-35) 2004. University of Gdańsk ISSN 1897-3191.

[13]. Pirzan A.M. dan Pong-Masak P.R., 2008. Hubungan Keragaman Fitoplankton dengan Kualitas Air di Pulau Bauluang, Kabupaten Takalar, Sulawesi Selatan . B I O D I V E R S I T AS ISSN: 1412-033X Volume 9, Nomor 3, Juli 2008 Halaman: $217-221$

[14]. Saravi, H.N., Maklough A., Pourgholam R., Din Z., Foong S.Y. 2011. Multivariate analysis of water quality parameters and phytoplankton composition in the southern of Caspian Sea. International Aquatic Research. ISSN 2008-4935. Int Aquat Res (2011) 3: $205-216$

[15]. Siahaan, R., A. Indrawan, D. Soedharma dan L. Prasetyo. 2011. Kualitas Air Sungai Cisadane, Jawa Barat, Banten. Institut Pertanian Bogor. Bogor.

[16]. Soares M.C.,Huszar V. L. M., Roland R., 2007 . Phytoplankton Dinamics In Two Tropical Rivers With Different Degrees Of Human Impact (Southeast Brazil). River Research and Applications. Publish online 2 July2007 in Wiley InterSciene. (www.interscience.wiley.com) DOI: 10.1002/rra.987. River. Res. Applic. 23: 698-714 (2007).

[17]. Rodrigues, LC.; Train, S.; Bovo-Scomparin, VM.; Jati, S.; Borsalli, CCJ.; Marengoni, E. (2009). Interannual variability of phytoplankton in the main rivers of the Upper Paraná River floodplain, Brazil: influence of upstream reservoirs. Brazilian Journal of Biology. Braz. J. Biol. vol.69 no.2 supl.0 São Carlos June 2009. ISSN 1519-6984

[18]. Webber, D.F. and J.C. Roff. 1995. Influence of Kingston Harbor on the Phytoplankton Community of the Nearshore Hellshire Coast, Southern Jamaica. Bulletin of Marine Science vol. 59 pages 245-258.

[19]. Wetzel, R.G. 2001. Limnology. Academic Press, New York. 1006 pp.

[20]. Yamaji, I. 1982. Ilustrations of The Marine Plankton of Japan. Hoikusha Publishing Co., Ltd.17-13, 1-chome, Uemachi, Higashi-ku, Osaka, 540 Japan. 